\title{
Phytoestrogens regulate transcription and translation of vitamin D receptor in colon cancer cells
}

\author{
Liat Abovich Gilad, Oren Tirosh and Betty Schwartz \\ Faculty of Agricultural, Food and Environmental Quality Sciences, Institute of Biochemistry, Food Science and Nutrition, The Hebrew University of Jerusalem, \\ PO Box 12, Rehovot 76100, Israel \\ (Requests for offprints should be addressed to B Schwartz; Email: bschwart@agri.huji.ac.il)
}

\begin{abstract}
The present study assesses the effects of two isoflavones, genistein and glycitein, and equol - a product of intestinal bacterial metabolism of dietary isoflavones, on vitamin $\mathrm{D}$ receptor (VDR) expression in an intestinal HT29 cell line. Genistein and glycitein significantly upregulated the VDR transcription and translation in HT29 cells. The effect of equol was less pronounced.

Treating HT29 cells transfected with a vector containing the VDR promoter next to a luciferase reporter with genistein or glycitein resulted in significant upregulation of VDR promoter activity, in a manner similar to that induced by $17 \beta$-estradiol (E2). Again, the effect of equol was less pronounced. VDR luciferase promoter activity was upregulated most by genistein, then by glycitein and least by equol when the VDR promoter was cotransfected with estrogen receptor $\beta$.
\end{abstract}

Reporter gene and chromatin immunoprecipitation (ChIP) assays demonstrated that E2 upregulates AP-1 and Sp-1 sites present on the $V D R$ gene. In contrast, the same assays demonstrated that the Sp-1, but not AP-1, site is induced by the phytoestrogens.

Similar to E2, genistein, glycitein and the isoflavonoid metabolite equol induced higher concentrations of intracellular free calcium, an event that could provide the upstream mechanism(s) induced by E2 and phytoestrogens that initiates the signaling cascade which results in the activation of extracellular signal-regulated kinase (ERK) signaling pathways and modulation of $\mathrm{Sp}-1$ sites of the VDR gene, and culminates in enhanced VDR expression.

Journal of Endocrinology (2006) 191, 387-398

\section{Introduction}

We previously demonstrated that $17 \beta$-estradiol (E2) regulates the transcription and expression of vitamin D receptor (VDR) in vivo in rat colonocytes (Schwartz et al. 2000) and duodenocytes (Liel et al. 1999), and in vitro in HT29 human colon cancer cells and MCF7 breast cancer cells (Gilad et al. 2005), by binding to estrogen receptor $\beta$ (ER $\beta$ ) and upregulating signal transduction through extracellular signal-regulated kinase (ERK) $1 / 2$ and the activator protein 1 (AP-1) site in the VDR promoter (Gilad et al. 2005). Studzinski et al. (2005) have recently demonstrated that the activation of VDR which leads to monocytic differentiation of human myeloblastic HL60 cells includes the MAP/ERK kinase (MEK)-ERK and JNK mitogen-activated protein kinases (MAPKs) and their positive and negative regulators and a downstream effector $\mathrm{C} / \mathrm{EBP} \beta$. The signaling pathway is primarily activated in response to various intracellular factors, which are able to initiate intracellular signaling, ultimately causing altered regulation of gene expression (Nethrapalli et al. 2005, Zivadinovic \& Watson 2005, Alexaki et al. 2006). The transcription factors CREB, c-Myc, Ets, AP-1, NF-kB, and $\mathrm{Sp}-1$ are targets of the Raf-MEK-ERK cascade (Chang $\&$ Chen 2005).

$\mathrm{E} 2$ has been shown to increase the number of VDRs in an osteoblast-like cell line ROS $17 / 2 \cdot 8$, an increase associated with enhanced responsiveness of the cells to $1,25(\mathrm{OH})_{2} \mathrm{D}_{3}$ (Liel et al. 1992). Increased VDR expression as a result of E2 treatment has also been noted in other tissues and cell types, such as the uterus (Levy et al. 1984), liver (Chatterjee et al. 2005), and human breast cancer cells (Escaleira et al. 1993, Gilad et al. 2005). However, E2 has also been associated with enhanced breast and uterus carcinogenesis. Interest in soy and soybean constituents is driven primarily by reported potential health benefits in a variety of areas, including the prevention of cancer (Cross et al. 2004) and osteoporosis, improvement of bone health (Branca 1999, 2003, Branca \& Lorenzetti 2005), and a lowered risk of cardiovascular diseases (Cos et al. 2003, Dixon 2004, Valachovicova et al. 2004, Beck et al. 2005). Their estrogenic activities may play an important role in their health-enhancing properties.

Many plants produce compounds that possess estrogenic activity in animals and are thus called phytoestrogens. These compounds have some structural similarity to the mammalian 
estrogen E2, and the presence of a phenolic ring is a prerequisite for binding to the ER (Mueller et al. 2004).

Phytoestrogens are present in food as both aglycones and glucosides. The main phytoestrogens which are currently recognized are soybean isoflavones, mainly genistein, daidzein, and glycitein (mainly contained in soybean germ), and their glycosides (genistin, daidzin, and glycitin). The aglycone genistein ( $4^{\prime} 5,7$-trihydroxyisoflavone) is one of the primary isoflavones in soybeans. Soybeans also contain small amounts of glycitein (4',7-dihydroxy-6-methoxyisoflavone) and equol [7-hydroxy-3-4(hydroxyphenyl)], a phytoestrogen metabolite from soybeans of the colon microflora. The ER-binding studies have demonstrated that these phytoestrogens have higher binding affinity for $\operatorname{ER} \beta$ compared with ER $\alpha$ (Mueller et al. 2004). Genistein was found to be $>$ 1000 -fold more potent at triggering transcriptional activity with $\operatorname{ER} \beta$ (An et al. 2001), indicating that genistein has a preference for cells expressing mainly $\operatorname{ER} \beta$ versus those expressing mainly ER $\alpha$.

Estrogen induces rapid activation of MAPK in colon and breast cancer cells (Gilad et al. 2005). The question arises whether phytoestrogens can induce similar activation through phosphorylation. The rapid effects exerted by genistein on growth factor-related signaling pathways are also demonstrated in ER $\alpha$-positive MCF7 and ER-negative SKB3 cells, suggesting a potential mechanism by which genistein might affect the expression of genes responsive to factors acting through response elements, such as AP-1 and $\mathrm{Sp}-1$ (Maggiolini et al. 2004). The AP-1 transcription factor consists of dimers of the Fos (Fos, Fra1, Fra2, and FosB) and Jun (Jun, JunB, and JunD) families of basic leucine zipper domain proteins. AP-1 is involved in several biological processes, including differentiation, proliferation, apoptosis, and oncogenic transformation (Jochum et al. 2001). Sp-1 is a member of a large family of zinc finger proteins and was one of the first transcription factors identified in mammalian cells (Dynan \& Tjian 1983). The $S p-1$ gene is ubiquitously expressed in a wide variety of mammalian cells, suggesting that these cells require $\mathrm{Sp}-1$ as a promoter of essential genes (Suske 1999). In fact, GC boxes, which are Sp-1 binding sites, are often located near a large number of genes involved in cell growth and development (Black et al. 2001).

The present study was designed to investigate the effects of genistein, glycitein, and equol on signaling pathways in HT29 cells, and to determine whether these interactions affect VDR transcription and translation similarly, or differently from the previously observed effects of E2.

\section{Materials and Methods}

\section{Materials}

Genistein, glycitein, equol, and all other biochemicals were purchased from Sigma Chemical Co. Tissue-culture media and antibiotic antimycotic solution supplements were obtained from Biological Industries Ltd (Kibbutz, Beit Haemek, Israel). The PhosphoPlus p42/44 MAPK antibody kit was from New England Biolabs, Inc. (Beverly, MA, USA). Monoclonal human anti-VDR antibodies, anti-pan-Jun antibody (detects c-Jun, Jun B, and Jun C), and anti-Sp-1 antibody were from Santa Cruz Biotechnology, Inc. (Santa Cruz, CA, USA). Rabbit anti-ER $\beta$ polyclonal antibody was from Chemicon (Temecula, CA, USA), and ER $\alpha$ monoclonal antibody was from Cell Signaling Technology, Inc. (Beverly, MA, USA). The enhanced chemiluminescence (ECL) kit was from Amersham Biosciences. The protein determination kit, based on bicinchoninic acid, was obtained from Pierce (Rockford, IL, USA). ICI182, 780, a specific ER inhibitor, was from Tocris (Ellisville, MO, USA). To study the involvement of the MAPK signal-transduction pathway, the cells were treated with E2 and phytoestrogens in the presence or absence of $10 \mu \mathrm{M}$ of the MEK $1 / 2$ phosphorylation inhibitor UO126 from Calbiochem-Novabiochem Corp. (San Diego, CA, USA).

\section{Cell lines and culture conditions}

HT29 colon cancer cells were cultured in Dubecco Modified Eagle Medium (DMEM) supplemented with 10\% (w/v) fetal calf serum (FCS), 1\%(w/v) L-glutamine, and $0 \cdot 2 \%(\mathrm{w} / \mathrm{v})$ antibiotic antimycotic solution- 1 and were maintained under a humidified atmosphere and $5 \% \mathrm{CO}_{2}$ at $37{ }^{\circ} \mathrm{C}$. The cells were grown to $80-90 \%$ confluence and the medium was replaced every other day.

\section{Treatment of cells}

The cells were harvested, washed twice by centrifugation in PBS and then cultured in DMEM with phenol red (PR) or DMEM without PR supplemented with 10\% charcoalstripped FCS, $1 \%$ L-glutamine, and $0 \cdot 2 \%$ antibiotic antimycotic solution-1. Cells were treated with different concentrations of genistein, glycitein, or equol (from $10^{-8}$ to $10^{-5} \mathrm{M}$ ) dissolved in dimethyl sulfoxide (DMSO), or E2 (from $10^{-11}$ to $10^{-7} \mathrm{M}$ ) dissolved in ethanol. Control cultures included ethanol at a final concentration of $0.0067 \%$ $(\mathrm{v} / \mathrm{v})$ or DMSO at $0 \cdot 1 \%(\mathrm{v} / \mathrm{v})$ in the medium. For proliferation analyses, cells were exposed to a medium containing the designated treatments for 3 and 6 days. For combined treatments of E2 and phytoestrogens with vitamin $\mathrm{D}$, we exposed the cells for 6 days to $10^{-11} \mathrm{M} \mathrm{E} 2$, $10^{-5} \mathrm{M}$ genistein, $10^{-5} \mathrm{M}$ glycitein, $10^{-5} \mathrm{M}$ equol, i.e., concentrations of $\mathrm{E} 2$ and phytoestrogen that induce significant VDR upregulation.

\section{Transient transfections}

The $1.5 \mathrm{~kb}$ human VDR promoter fragment, inserted into the basic vector pGL2 containing the luciferase reporter gene, was a generous gift from Prof. H F DeLuca (Department of Biochemistry, University of Wisconsin, Madison, WI, USA). 
VDR promoter was cotransfected with the ER $\beta$ expression plasmid (a generous gift from Prof. M Muramatsu, Department of Biochemistry, Saitama Medical School, Japan), pCXN2-hER $\beta$. Empty pCXN2 was cotransfected in control cells. The $3 \times$ AP-1-LUC and the $3 \times$ Sp-1-LUC plasmids were constructed by insertion of a double-stranded 40-mer deoxyoligonucleotide containing three copies of the $\mathrm{AP}-1$ or $\mathrm{Sp}-1$ consensus sequences in the upstream region of the SV40 promoter at the XhoI site of the pGL3 promoter (Promega Corp.).

In all the transient transfections, a vector expressing $\beta$ galactosidase $(\beta$-gal) was always cotransfected in order to standardize the transfection assay. Plasmids were transfected using lipofectin 2000 (GIBCO/BRL, Paisley, UK). An unmodified pGL2 basic vector with no promoter activity was used as a control. The stimulation of Sp-1 or AP-1-LUC vectors and the VDR promoter was induced by treatment of transfected cells for $48 \mathrm{~h}$ with $10^{-5} \mathrm{M}$ genistein, glycitein, or equol, or $10^{-10} \mathrm{M} \mathrm{E2}$. Luciferase activity was assessed in each sample and standardized relative to $\beta$-gal activity. All the experiments were performed in triplicate.

\section{Protein determination}

Protein concentration in the different cell lysates was determined by a micro bicinchoninic acid-based protein assay using BSA as the standard protein.

\section{Western-blot analysis}

The cells were lysed, electrophoresed on a $10 \%$ sodium dodecyl sulfate (SDS) polyacrylamide gel, transferred to a nylon membrane (Amersham Biosciences), blocked in $10^{-3} \mathrm{M}$ Tris-base and $0 \cdot 1 \mathrm{M}$ sodium chloride containing $5 \%(\mathrm{w} / \mathrm{v})$ dry non-fat milk, incubated with monoclonal human antiVDR antibody, and subsequently incubated with a secondary antibody coupled to horseradish peroxidase. Proteins were visualized using an ECL kit (Amersham Biosciences). The signal intensities were analyzed by a BAS1000 Bio-Image Analyzer (Fujix, Tokyo, Japan) and the densities were quantified with the NIH computer program ImageJ 1.19.

To determine ERK1/2 phosphorylation, the cells were plated in six-well plates in DMEM-PR and gradually deprived of FCS as follows: cells were exposed for 2 days to $0 \cdot 5 \%$ charcoal-stripped FCS-DMEM-PR, and then to media devoid of FCS for $48 \mathrm{~h}$ including different concentrations of genistein, glycitein, or equol. Western-blot was performed on cell lysates using a rabbit polyclonal phospho-p42/44 MAPK (Thr202/Tyr204) antibody.

\section{RT-PCR analyses}

RNA isolation was performed using Tri Reagent solution (MRC, Cincinnati, OH, USA). RT-PCR assay was performed using the Promega kit assay. The specific selected VDR primers were as follows: $5^{\prime}$-ATGCCATCTGCATCGTCTC- $3^{\prime}$ and
5'-GCACCGCACAGGCTGTCCTA-3'. The PCR protocol was $5 \mathrm{~min}$ at $94{ }^{\circ} \mathrm{C}$, then 31 cycles $\left(1 \mathrm{~min}, 94^{\circ} \mathrm{C} ; 1 \mathrm{~min}\right.$, $54{ }^{\circ} \mathrm{C} ; 1 \mathrm{~min}, 72{ }^{\circ} \mathrm{C}$ ), and finally $10 \mathrm{~min}$ at $72{ }^{\circ} \mathrm{C}$.

\section{Chromatin immunoprecipitation (ChIP) assay}

The cells were treated as above with E2 and phytoestrogens for $48 \mathrm{~h}$. ChIP assay was performed essentially as described by Yan et al. (2001). Cells were treated with $1 \%(\mathrm{v} / \mathrm{v})$ formaldehyde, followed by the addition of $0 \cdot 125 \mathrm{M}$ glycine. The cells were pelleted and resuspended in $200 \mu \mathrm{l}$ SDS lysis buffer $(1 \% \mathrm{w} / \mathrm{v}$ SDS, $10 \mathrm{mMEDTA}$, and $50 \mathrm{mM}$ Tris-HCl, $\mathrm{pH} 8 \cdot 1)$ containing protease inhibitors, and cell nuclei were isolated using a Dounce homogenizer and pelleted. The nuclear fraction was then sonicated with a sonic dismembrator (Fisher, Pittsburgh, PA, USA) at $80 \%$ maximum power for six 20 s pulses on ice. Nuclear lysates were diluted tenfold in immunoprecipitation buffer (0.01\% SDS, $1 \cdot 1 \% \mathrm{w} / \mathrm{v}$ Triton X-100, $1.2 \mathrm{mM}$ EDTA, $16.7 \mathrm{mM}$ Tris- $\mathrm{HCl}, \mathrm{pH} 8 \cdot 1,167 \mathrm{mM} \mathrm{NaCl}$, and protease inhibitors). Chromatin solutions were incubated overnight at $4{ }^{\circ} \mathrm{C}$ with $5 \mu \mathrm{g}$ anti-pan-Jun antibody (a major component of the transcription factor AP-1) or $5 \mu \mathrm{g} \mathrm{Sp}-1$ antibody, or control rabbit $\operatorname{IgG}$ antibody. The immune complexes were then mixed with $60 \mu \mathrm{l}$ of $50 \%(\mathrm{w} / \mathrm{v})$ protein A/G plus agarose (Santa Cruz Biotechnology Inc.) saturated with salmon sperm dsDNA (Superarray, Frederick, MD, USA). The immune complexes were eluted by adding $250 \mu \mathrm{l} 1 \%$ SDS in $0 \cdot 1 \mathrm{M} \mathrm{NaHCO}_{3}$ to the pelleted beads and then incubated at room temperature for $15 \mathrm{~min}$. Then $20 \mu \mathrm{l}$ of $5 \mathrm{M} \mathrm{NaCl}$ were added with $1 \mu \mathrm{g}$ RNase (Sigma Chemical Co.). The complexes were incubated at $65{ }^{\circ} \mathrm{C}$ for $4 \mathrm{~h}$. The DNA was recovered by ethanol precipitation and purified by using QiaQuick spin columns (Qiagen). The eluted DNA was dissolved in $20 \mu \mathrm{l}$ Tris-EDTA (TE) buffer and analyzed by PCR. VDR promoter primer sequences were: $5^{\prime}$-TGGTTGCAGCGCCAACGGAG-3' and $5^{\prime}$-AACTGTTCGTCTCTGTCGGGT- $3^{\prime}$. The reaction was subjected to an initial denaturation step for $5 \mathrm{~min}$ at $95{ }^{\circ} \mathrm{C}$ followed by 30 cycles of denaturation $\left(0.5 \mathrm{~min}\right.$ at $\left.94^{\circ} \mathrm{C}\right)$, annealing $\left(0.5\right.$ min at $\left.58{ }^{\circ} \mathrm{C}\right)$, and extension $\left(0.5 \min\right.$ at $\left.72{ }^{\circ} \mathrm{C}\right)$. Then the reaction was subjected to a final extension time of $5 \mathrm{~min}$ at $72{ }^{\circ} \mathrm{C}$. PCR products were analyzed on a $2 \%$ agarose gel containing ethidium bromide.

\section{Intracellular free calcium}

Intracellular free calcium ions $\left[\mathrm{Ca}^{2+}\right]$ were detected after treatment with E2 $\left(10^{-10} \mathrm{M}\right)$, or $10^{-5} \mathrm{M}$ genistein, glycitein, or equol for $8 \mathrm{~h}$ by acetomethoxyl (AM) ester of calcium green-1 (Molecular Probes, Eugene, OR, USA) according to the protocol provided by the manufacturer using a FACSstar flow cytometer (BD Biosciences, Mansfield, MA, USA); 10000 events were acquired for every sample and analyzed using the CellQuest program (BD Biosciences). Each experimental treatment was performed in duplicate. 


\section{Statistical analyses}

Data presented represent mean士s.E.M. or S.D. Differences between the controls and the treatments were evaluated by Student's $t$-test.

\section{Results}

Effect of E2, genistein, glycitein, or equol on intracellular calcium in HT29 cells

The effect of isoflavones on intracellular free calcium was evaluated as an initial indication for their activity. We expected a rise in free calcium following treatment with E2 and E2-related agonists, in a manner similar to that previously reported (Dopp et al. 1999). Indeed, Table 1 shows an increase in free calcium following $8 \mathrm{~h}$ treatment with the isoflavones genistein and glycitein, as well as with E2, but not with equol, while EGTA AM (ethylene-bis(oxyethylenenitrilo) tetraacetic acid tetraacetoxy methyl ester), a calcium chelator, scavenged the calciumdependent fluorescent signal. These results indicate a direct effect on intracellular calcium mobilization by isoflavones.

Effect of E2, genistein, glycitein, or equol, or a combined treatment of each with vitamin D on proliferation of HT29 cells

When HT29 cells were treated with several concentrations of E2 (not shown), equol, or glycitein (at concentrations of $10^{-4}$ to $\left.10^{-8} \mathrm{M}\right)$, HT29 proliferation was not affected and remained the same as control cells (Fig. 1B and C). E2 at concentrations of $10^{-7}$ to $10^{-11} \mathrm{M}$ did not exert any significant effect on HT29 proliferation after 3 or 6 days. However, when HT29 cells were exposed to increasing concentrations of genistein $\left(10^{-4}-10^{-8} \mathrm{M}\right)$, a dose-dependent inhibition of proliferation was obtained.

Table 1 Intracellular free calcium following treatment with E2 and phytoestrogens

Calcium-green 1

fluorescence (mean \pm s.D.)

$\begin{array}{ll}\text { Treatment } & \\ \text { C1 } & 276 \pm 15 \\ \text { C2 } & 254 \pm 20 \\ \text { E2 } & 526 \pm 51^{*} \\ \text { Genistein } & 395 \pm 48^{*} \\ \text { Glycitein } & 307 \pm 45^{+} \\ \text {Equol } & 298 \pm 45 \\ \text { EGTA AM } & 125 \pm 15^{*}\end{array}$

Cells were treated with E2 $\left(10^{-8} \mathrm{M}\right)$, or genistein, glycitein, or equol $\left(10^{-5} \mathrm{M}\right)$ for $8 \mathrm{~h}$. Intracellular free calcium was detected using acetomethoxyl (AM) ester of calcium green-1 relative to $\mathrm{C} 1$ (control cells containing $0 \cdot 01 \%$ DMSO) or $\mathrm{C} 2$ (control cells containing $0.0067 \%$ ethanol $(\mathrm{EtOH})$ ). For specificity of intracellular free calcium determinations we used EGTA AM $\left(8 \times 10^{-6} \mathrm{M}\right)$. ${ }^{*} P<0 \cdot 01,{ }^{+} P<0 \cdot 05$ compared with the respective controls, C1 for E2, C2 for phytoestrogens. S.D. $=$ standard deviation.
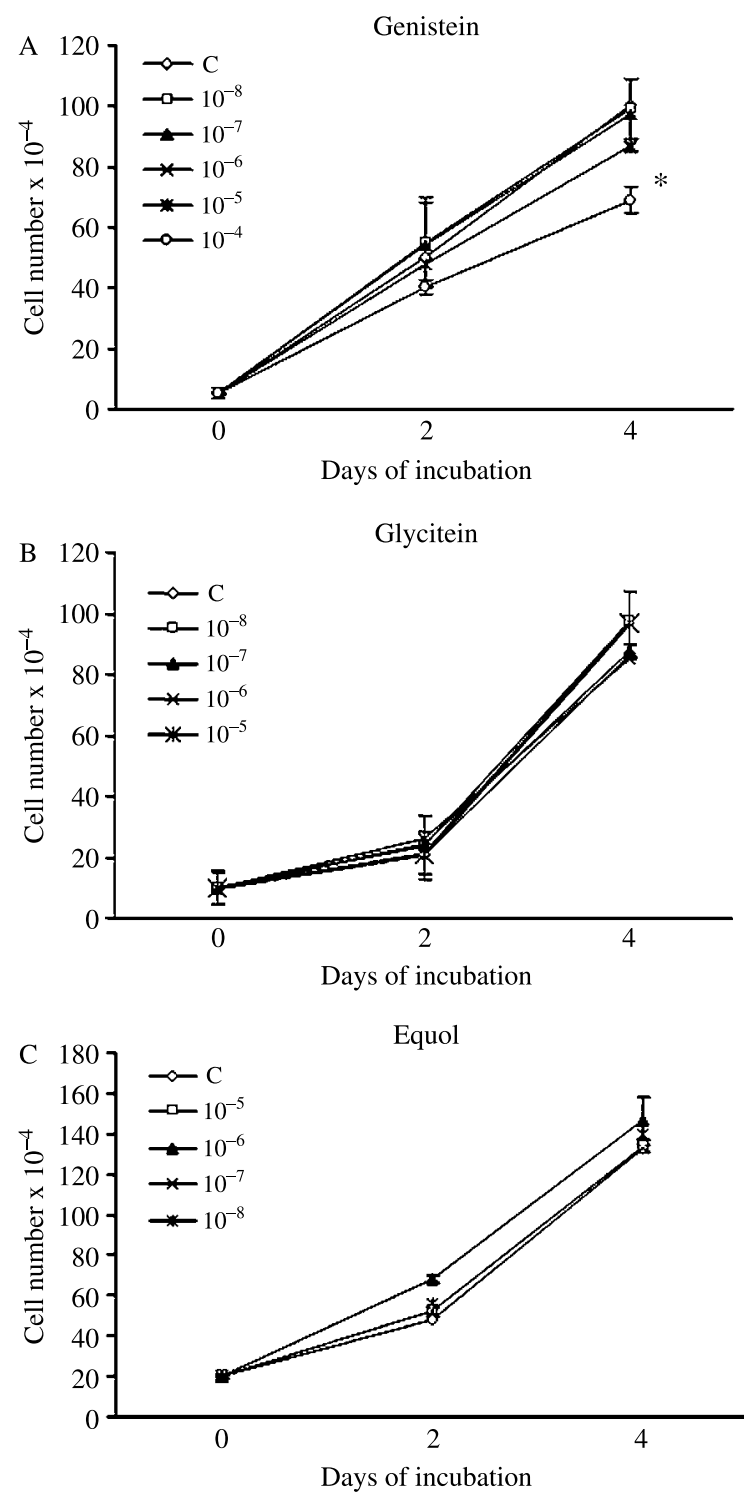

Figure 1 Effect of phytoestrogens on HT29 cancer cell growth. HT29 cells were treated with different concentrations of genistein (A), glycitein (B), or equol (C) for 3 and 6 days. Medium was replaced every other day. Control cells were treated with the phytoestrogen vehicle (DMSO) at the maximum concentration used in the experiment, $0 \cdot 01 \% .{ }^{*} P<0 \cdot 05$.

When HT29 cells were exposed to combined treatment of E2, genistein, or glycitein with vitamin D for 6 days, the effect of the combined treatments on proliferation was more significant than treating HT29 cells with vitamin D alone (Fig. 2). A similar trend was observed following 3 days of incubation, but results only reached statistical significance at 6 days of incubation (not shown). This was not the case when the cells were treated with a combination of equol and vitamin $\mathrm{D}$, at either 3 (not shown) or 6 days of incubation, relative to vitamin $\mathrm{D}$ alone. 


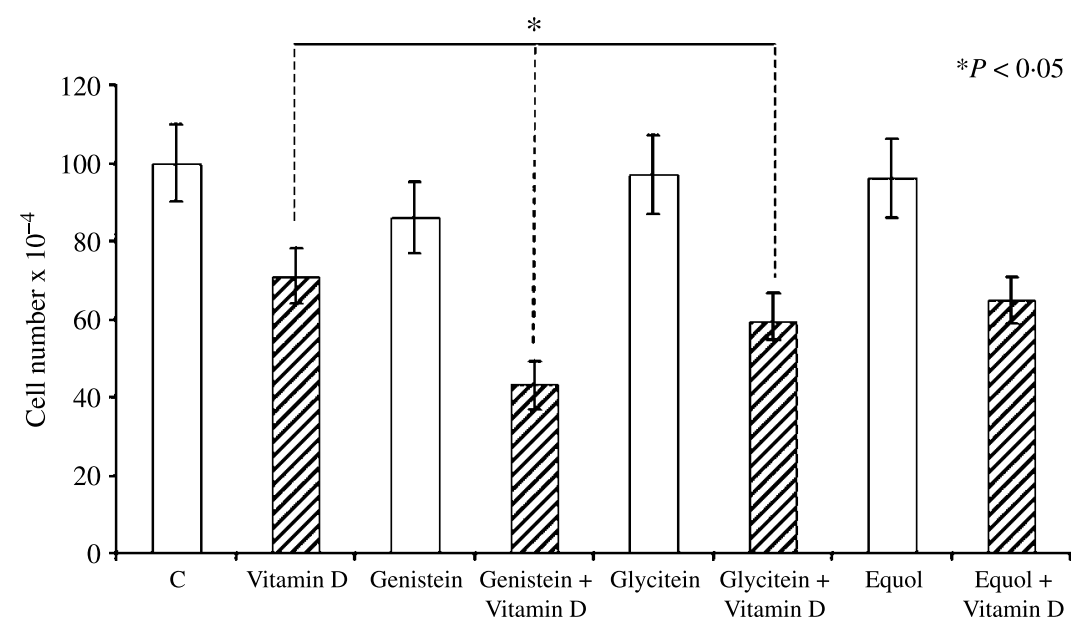

Figure 2 Effects of combined phytoestrogen + vitamin D treatment on HT29 cancer cell growth. Cells were exposed for 6 days to individual or combined treatments of $10^{-5} \mathrm{M}$ phytoestrogen and $10^{-8} \mathrm{M}$ vitamin $\mathrm{D}$. Control cells $(\mathrm{C})$ were treated with vehicle control $\left(0 \cdot 01 \%\right.$ DMSO). ${ }^{*} P<0 \cdot 05$, comparison between vitamin $\mathrm{D}$ and vitamin $\mathrm{D}+$ genistein or vitamin D+glycitein.

Effect of genistein, equol, or glycitein on VDR protein expression compared with E2

We examined the upregulation of VDR protein expression following the exposure of HT29 cells to the phytoestrogens genistein, glycitein, or equol for 6 days, as compared with E2's effect, by western-blot analysis. Phytoestrogens exerted a milder upregulatory effect on VDR expression relative to the significant upregulation obtained following E2 treatment at much lower concentrations (Fig. 3A-D). Genistein was the most effective phytoestrogen in upregulating VDR expression, the effects being evident at concentrations of $10^{-8} \mathrm{M}$ and becoming gradually more significant at $10^{-7}$ and $10^{-6} \mathrm{M}$ (Fig. 3B). Glycitein also upregulated VDR expression, exerting a peak effect at a concentration of $10^{-6} \mathrm{M}$ (Fig. 3C). Equol was only effective in upregulating VDR expression at its maximal concentration $\left(10^{-5} \mathrm{M}\right.$, Fig. 3D).

Effect of E2, genistein, glycitein or equol on VDR $m R N A$ levels in HT29 colon cancer cells

When HT29 cells were treated for 6 days with $10^{-5} \mathrm{M}$ genistein, glycitein or equol VDR transcription was effectively upregulated (Fig. 4). The effect exerted by the phytoestrogens was comparable with that on mRNA expression following treatment with $10^{-8} \mathrm{M}$ E2. Again, similar to E2, phytoestrogens seem to upregulate transcription of the VDR gene.

The role of ERs in VDR regulation by E2, genistein, glycitein, or equol

Combined treatment with E2, genistein, equol, or glycitein and the specific ER inhibitor ICI182, 780 for 6 days inhibited
E2, genistein, and glycitein-mediated activation of VDR (Fig. 5). Equol was ineffective in this regard, and therefore the effect of ICI182, 780 was not measurable. This finding suggests that phytoestrogens regulate VDR in HT29 cells similar to E2-mediated VDR expression, i.e., via a process involving ER (Gilad et al. 2005).

\section{Transfection assays}

To demonstrate whether phytoestrogens have a direct effect on transcriptional activity of the VDR promoter, we performed transient transfection assays in HT29 cells with the luciferase reporter vector pGL2 containing the $1.5 \mathrm{~kb}$ region of VDR. The transfected cells were treated for $48 \mathrm{~h}$ with genistein $\left(10^{-6}\right.$ and $\left.10^{-5} \mathrm{M}\right)$, glycitein $\left(10^{-6}\right.$ and $\left.10^{-5} \mathrm{M}\right)$, or equol $\left(10^{-6}\right.$ and $10^{-5} \mathrm{M}$ ), and their effects were compared with that exerted by E2 $\left(10^{-8}\right.$ and $\left.10^{-10} \mathrm{M}\right)$. All of these treatments upregulated luciferase activity on their own, similar to E2 (Fig. 6A-D). Upregulation of VDR expression following treatment with E2 or genistein was most significant when ER $\beta$ was cotransfected with the VDR promoter in HT29 cells; with glycitein, the upregulatory effect was less pronounced and with equol, coexpression of VDR with ER $\beta$ did not add to the effect of the phytoestrogen alone.

Phosphorylation of ERK 1/2 by glycitein, genistein, and equol

We previously demonstrated upregulation of VDR by E2 through activation of the ERK1/2 signaling pathway (Gilad et al. 2005). The present study aimed to assess whether, similar to E2, genistein, equol, or glycitein can induce rapid cellular signaling effects. To this end, we measured ERK 1/2 
A E2 (M)

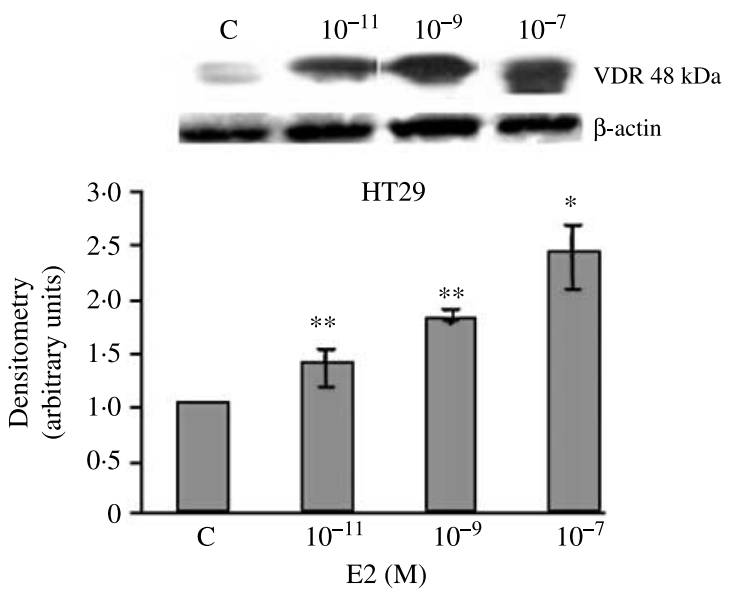

$\mathrm{C}$

Glycitein (M)
B

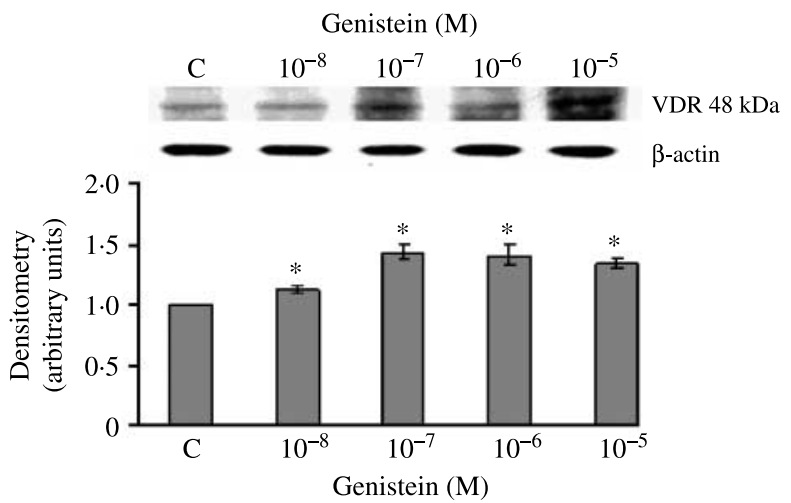

$\mathrm{D}$
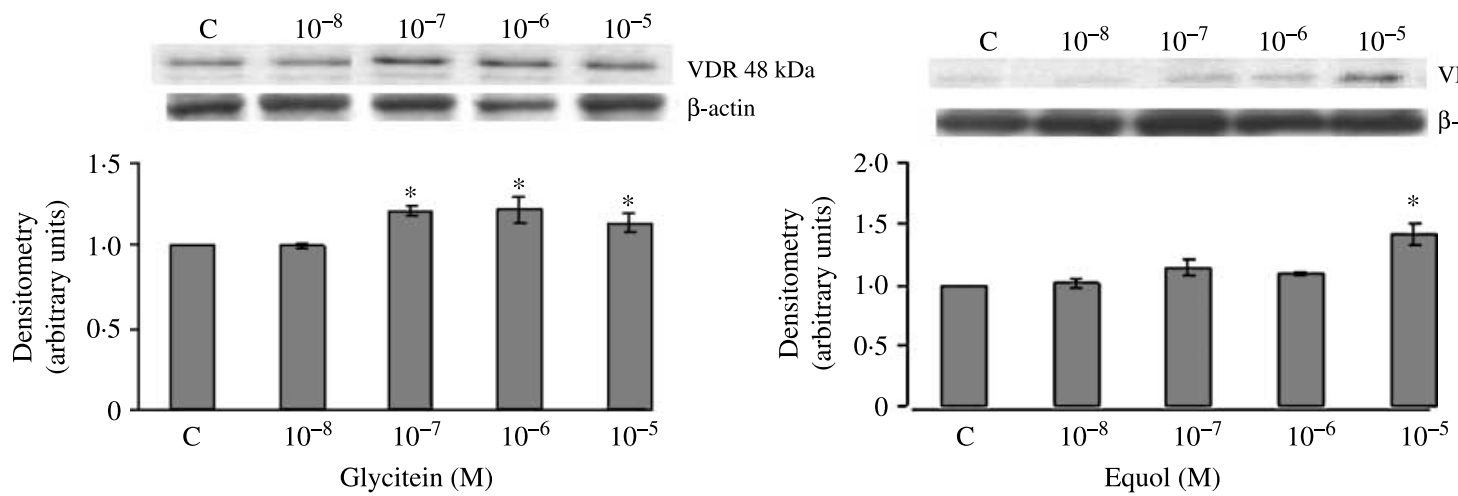

Figure 3 VDR protein expression. HT29 cells were treated with different concentrations of E2 (A), genistein (B), glycitein (C), or equol (D) for 6 days. Medium and treatment were replaced every other day. Cell extracts were analyzed by SDS-PAGE and immunoblotting using anti-VDR antibody. One representative experiment from three identical ones is shown. Densitometric analysis of VDR westernblot, expressed in arbitrary units relative to control $(\mathrm{C})$ treated with $0 \cdot 0067 \% \mathrm{EtOH}(\mathrm{A})$ or $0 \cdot 01 \% \mathrm{DMSO}((\mathrm{B})-(\mathrm{D})) * P<0 \cdot 05, * * P<0 \cdot 01$.

phosphorylation following treatment with these phytoestrogens. Genistein and glycitein activated ERK 1/2 phosphorylation within 5 min of exposure to a concentration of $10^{-5} \mathrm{M}$ (Fig. 7B and C), similar to E2 (Fig. 7A); in contrast, equol only exerted ERK $1 / 2$ activation following $10 \mathrm{~min}$ of exposure (Fig. 7D), while shorter exposure periods did not induce any phosphorylation activity.

The effect of phytoestrogens on the activity of Sp-1 or AP-1 transcription factors

The luciferase reporter expression vector $3 \times \mathrm{Sp}-1-\mathrm{LUC}$ was transfected into HT29 cells, which were then treated with different concentrations of E2, genistein, glycitein, or equol for $48 \mathrm{~h}$. The cells were then analyzed for luciferase activity. We found similar and significant upregulation of Sp-1-dependent transcriptional activity induced by E2, genistein, and glycitein (Fig. 8A-C); upregulation was less striking for equol (Fig. 8D).

Similarly, the luciferase reporter expression vector $3 \times \mathrm{AP}-$ 1-LUC was transfected into HT29 cells, which were then treated with E2, genistein, glycitein, or equol. The cells were analyzed for luciferase activity, and we found upregulation of AP-1-dependent transcriptional activity only following exposure to E2 $\left(10^{-8}\right.$ and $10^{-10} \mathrm{M}$; Fig. 9A), but not to any of the phytoestrogens tested in the present study, i.e., genistein (Fig. 9B), glycitein (Fig. 9C), or equol (Fig. 9D) at

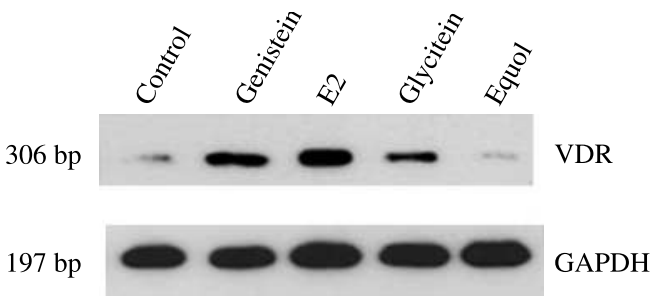

Figure 4 VDR mRNA expression. Cells were treated with $10^{-8} \mathrm{M}$ $\mathrm{E} 2$ or $10^{-5} \mathrm{M}$ genistein, glycitein, or equol for 6 days. Cells extracts were analyzed for VDR mRNA expression by RT-PCR as compared with glyceraldehyde-3-phosphate dehydrogenase (GAPDH) expression. 


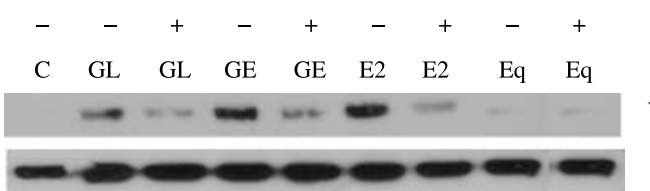

ICI182, 780

VDR $48 \mathrm{kDa}$

$\beta$ actin

Figure 5 Effect of ICI182, 780 on VDR protein expression. Cells were treated with $10^{-8} \mathrm{M} \mathrm{E2}$, or $10^{-5} \mathrm{M}$ genistein (GE), glycitein $(\mathrm{GL})$, or equol $(\mathrm{Eq})$ for 6 days in the presence or absence of the E2 receptor inhibitor ICI182, $780\left(10^{-6} \mathrm{M}\right)$. The blots were stripped and re-probed with $\beta$-actin, which was used as a loading control. One representative experiment of three identical ones is shown.

$10^{-6}$ and $10^{-5} \mathrm{M}$, concentrations which had proven effective at upregulating $\mathrm{Sp}-1$ activity and ERK1/2 phosphorylation.

\section{UO126 inhibits E2- and phytoestrogen-mediated VDR expression}

In order to link MAPK activation with $\mathrm{Sp}-1$ activation and VDR expression, we exposed wild-type HT29 cells or HT29 cells transfected with $3 \times \mathrm{Sp}-1-\mathrm{LUC}$ to E2 $\left(10^{-8} \mathrm{M}\right)$ and the phytoestrogens genistein, glycitein, or equol $\left(10^{-5} \mathrm{M}\right)$ concomitantly with $10 \mu \mathrm{M}$ of the MEK1 and MEK2 inhibitor UO126. UO126 downregulated E2 and phytoestrogen-mediated upregulation of $\mathrm{Sp}$-1-dependent transcriptional activity (Fig. 10A) and concomitantly inhibited dramatically VDR expression (Fig. 10B) indicating that MAPK signaling cascade is directly related to the control of VDR expression and $\mathrm{Sp}-1$ activation by $\mathrm{E} 2$ and phytoestrogens.

\section{ChIP analysis of VDR promoter}

The regulatory region of the VDR promoter, covering the amino acid sequence from -120 to +10 (Fig. 11B), contains one AP-1 site and multiple (5) Sp-1 binding motifs. Luciferase assays testing the role of E2 and phytoestrogens in $\mathrm{AP}-1$ and $\mathrm{Sp}-1$ transcriptional activity revealed that $\mathrm{Sp}-1$ is regulated, while AP-1 is not, following treatment with phytoestrogens, whereas both the transcription factors are upregulated following treatment with $\mathrm{E} 2$. The in vivo association of AP-1 and Sp-1 with the regions on the VDR promoter known to bind these transcription factors following the treatment with E2 was confirmed by ChIP assay. Chromatin fragments were treated briefly with formaldehyde to cross-link DNA-binding proteins to the chromatin of control HT29 cells or of those stimulated with E2 or phytoestrogens. The isolated chromatin was subjected to sonication followed by immunoprecipitation with c-pan-Jun
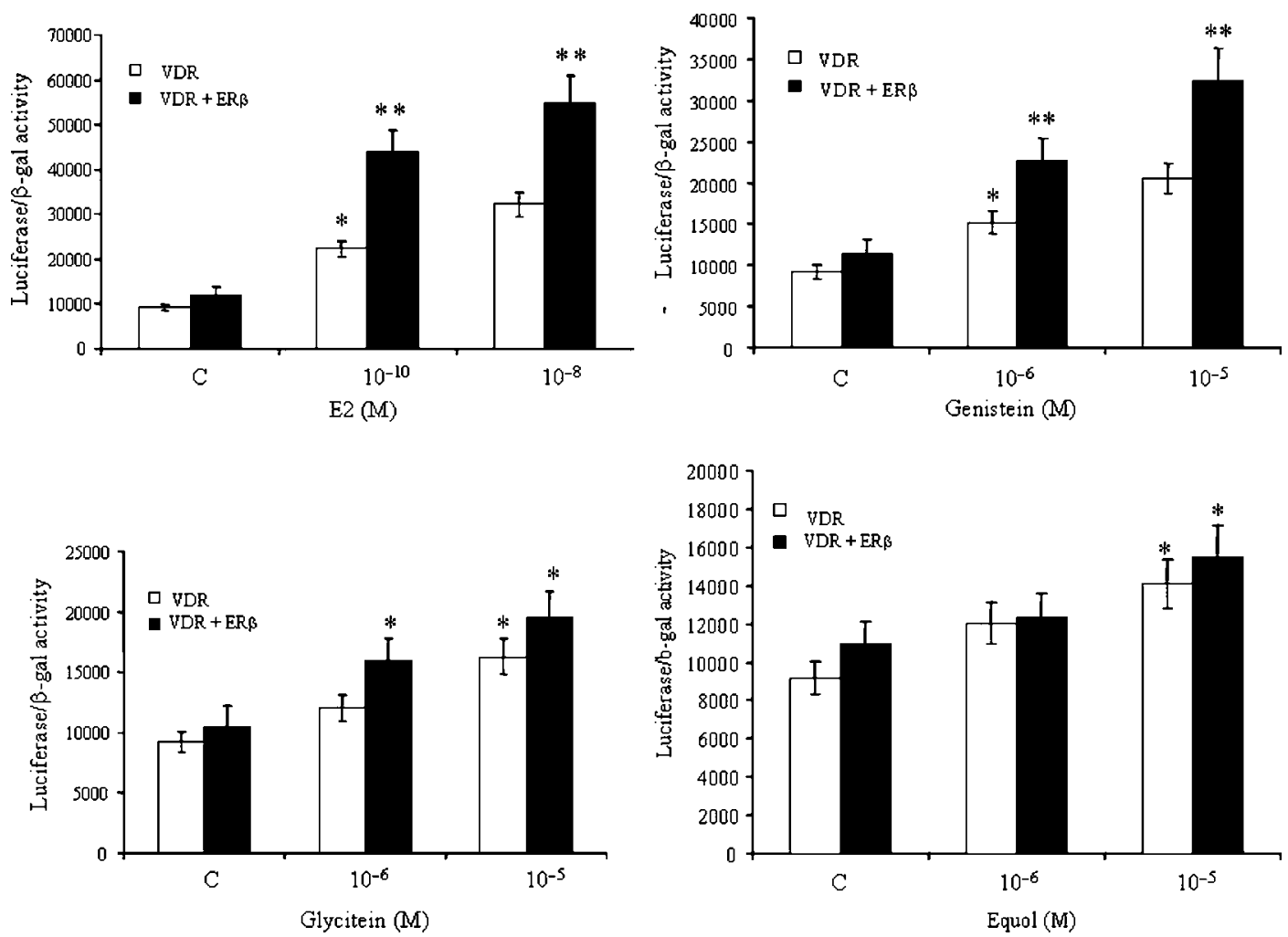

Figure 6 Effect of ER $\beta$ expression on VDR promoter activity. HT29 cells were transfected with plasmids containing the $1.5 \mathrm{~kb}$ hVDR promoter fragment in a pGL2 basic vector in front of the luciferase reporter gene concomitant with pCXN2-hER $\beta$, an ER $\beta$ expression plasmid (or the appropriate empty pCXN2 control vector) and then treated with $10^{-8}$ and $10^{-10} \mathrm{ME} 2(\mathrm{~A})$ and $10^{-6}$ or $10^{-5} \mathrm{M}$ genistein (B), glycitein (C), or equol (D). Cells were analyzed for luciferase activity following $48 \mathrm{~h}$ of treatment $(* P<0 \cdot 05, * * P<0 \cdot 01)$. 
A

$$
\begin{aligned}
& \text { Time (Min) } \\
& \text { E2 } 10^{-11} \mathrm{M}
\end{aligned}
$$$$
\begin{array}{lllll}
\text { C } & 5 & 10 & 15 & 20
\end{array}
$$

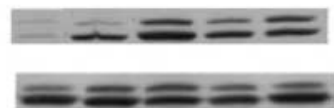

P ERK1/2

Total

B

$\begin{array}{llllll}\text { Time (Min) } & \mathrm{C} & 5 & 10 & 15 & 20\end{array}$

Genistein $10^{-5} \mathrm{M}$

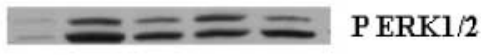

Total

C

Time (Min)

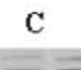

$5 \quad 10$

$10 \quad 15$

1520

Glycitein $10^{-5} \mathrm{M}$

$=\equiv= \pm$ Total

D

Time (Min)

C $510 \quad 15$

$15 \quad 20$

Equol $10^{-5} \mathrm{M}$

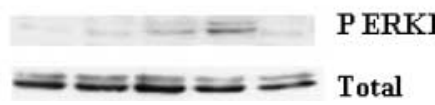

Figure 7 MAPK activation in HT29 cells. Cells were cultured in PR-free DMEM without FCS for $48 \mathrm{~h}$ and then treated for 5-20 min with $10^{-8} \mathrm{ME2}(\mathrm{A}), 10^{-5} \mathrm{M}$ genistein (B), $10^{-5} \mathrm{M}$ glycitein (C), or $10^{-5} \mathrm{M}$ equol (D). Control cells (C) were treated with $0 \cdot 0067 \% \mathrm{EtOH}(\mathrm{A})$ or $0 \cdot 01 \%$ DMSO ((B)-(D)). MAPK was probed with anti-MAPK antibodies (anti-ERK1 and ERK2) to detect total MAPK band expression, or with anti-phospho-MAPK antibody to detect phosphorylated proteins. or Sp-1 antibody, and the DNA from the immunoprecipitates was isolated. From this DNA, a $180 \mathrm{bp}$ fragment of the VDR promoter containing the AP- 1 and $\mathrm{Sp}-1$ sites $(-120$ to +10 , Fig. 11B) was amplified by PCR. Figure 11A shows that the level of pan-Jun cross-linked to the VDR-AP-1 site of the VDR promoter increased only in cells exposed to E2 relative to controls, whereas in cells exposed to phytoestrogens, no effect was observed. In addition, Fig. 11A shows that the level of Sp-1 cross-linked to the VDR-Sp-1 sequence of the VDR promoter was dose-dependently increased in cells treated with genistein, glycitein, and E2 relative to the control, while the effect of equol was less pronounced.

\section{Discussion}

The isoflavones genistein and glycitein, as well as E2, but not equol, affected intracellular free calcium concentrations, indicating a direct effect on intracellular calcium mobilization by isoflavones. We tested calcium mobilization since previous studies have indicated that estrogens or estrogenic-like substances trigger the release of $\mathrm{Ca}^{2+}$ from intracellular stores. This finding suggests that the agonist activates a cell surface receptor rather than the conventional slowly acting, genestimulating nuclear ER (Morley et al. 1992, Dopp et al. 1999). This direct non-genomic effect may be one of the earliest signals of these molecules in intestinal cells. We aimed at assessing whether isoflavones, through additional nongenomic pathways, have the ability to upregulate VDR
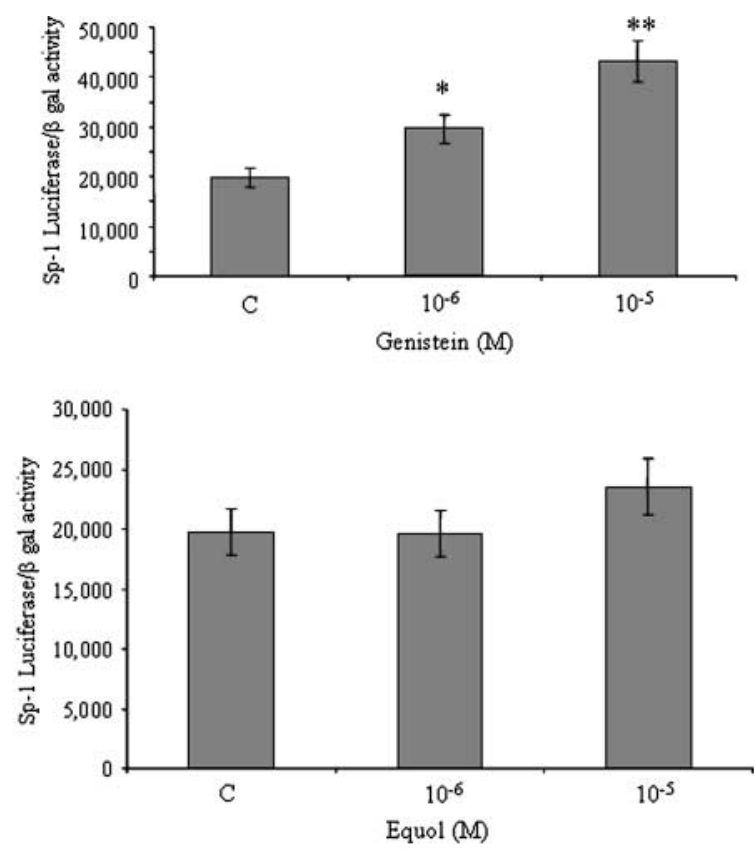

Figure 8 Effect of estrogen or phytoestrogen treatment on Sp-1 transcription factor. HT29 cells were transfected with plasmids containing the $3 \times \mathrm{Sp}-1$ fragment in a pGL2 basic vector in front of the luciferase reporter gene and then treated with different concentrations of E2 (A), genistein (B), glycitein (C), or equol (D) for $48 \mathrm{~h}$. Cells were analyzed for luciferase activity $(* P<0 \cdot 05, * * P<0 \cdot 01)$. 

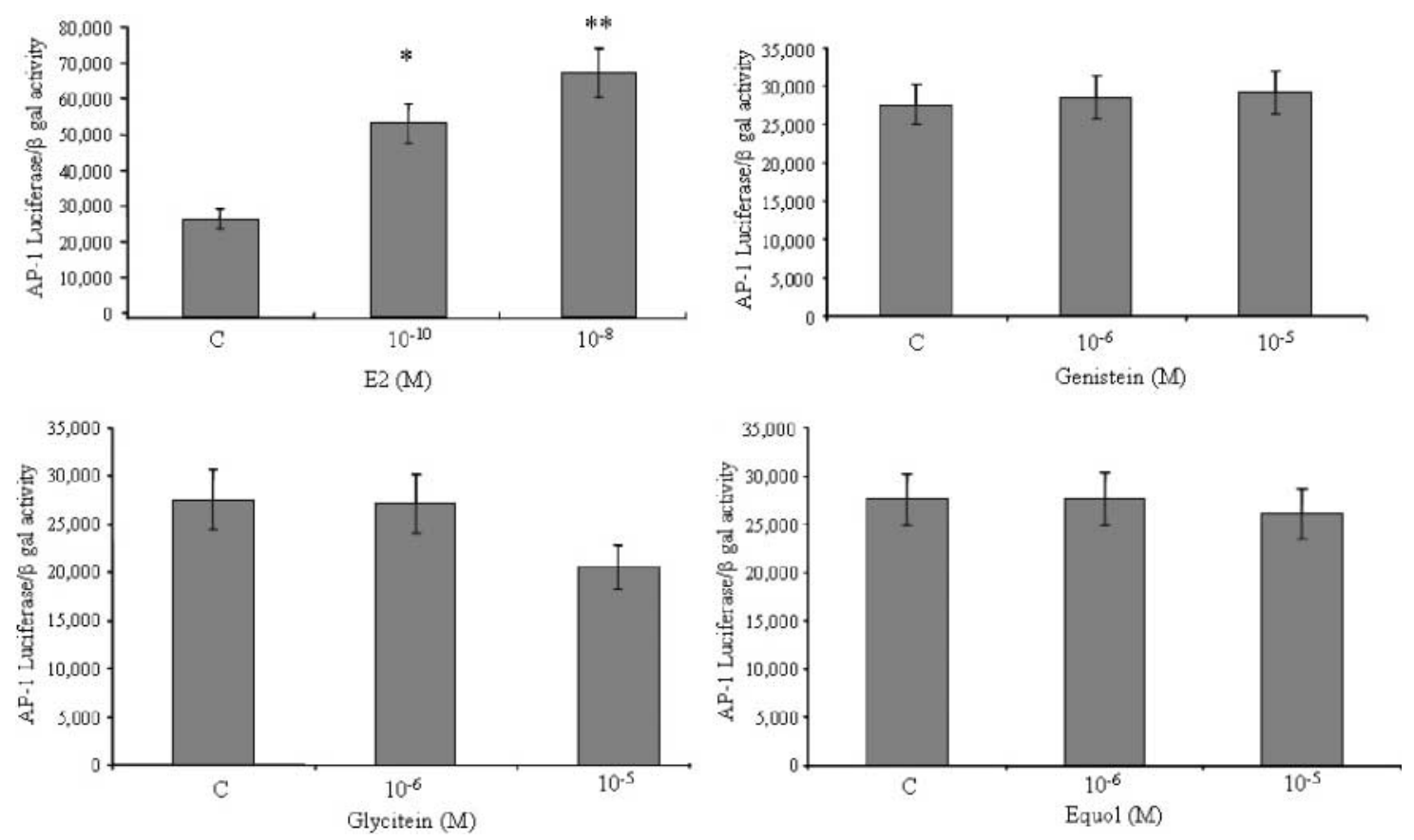

Figure 9 Effect of estrogen or phytoestrogen treatment on AP-1 transcription factor. HT29 cells were transfected with plasmids containing the $3 \times \mathrm{AP}-1$ fragment in a pGL2 basic vector in front of the luciferase reporter gene and then treated with different concentrations of E2 (A), genistein (B), glycitein (C), or equol (D) for $48 \mathrm{~h}$. Cells were analyzed for luciferase activity $\left({ }^{*} P<0 \cdot 05,{ }^{* *} P<0 \cdot 01\right)$.

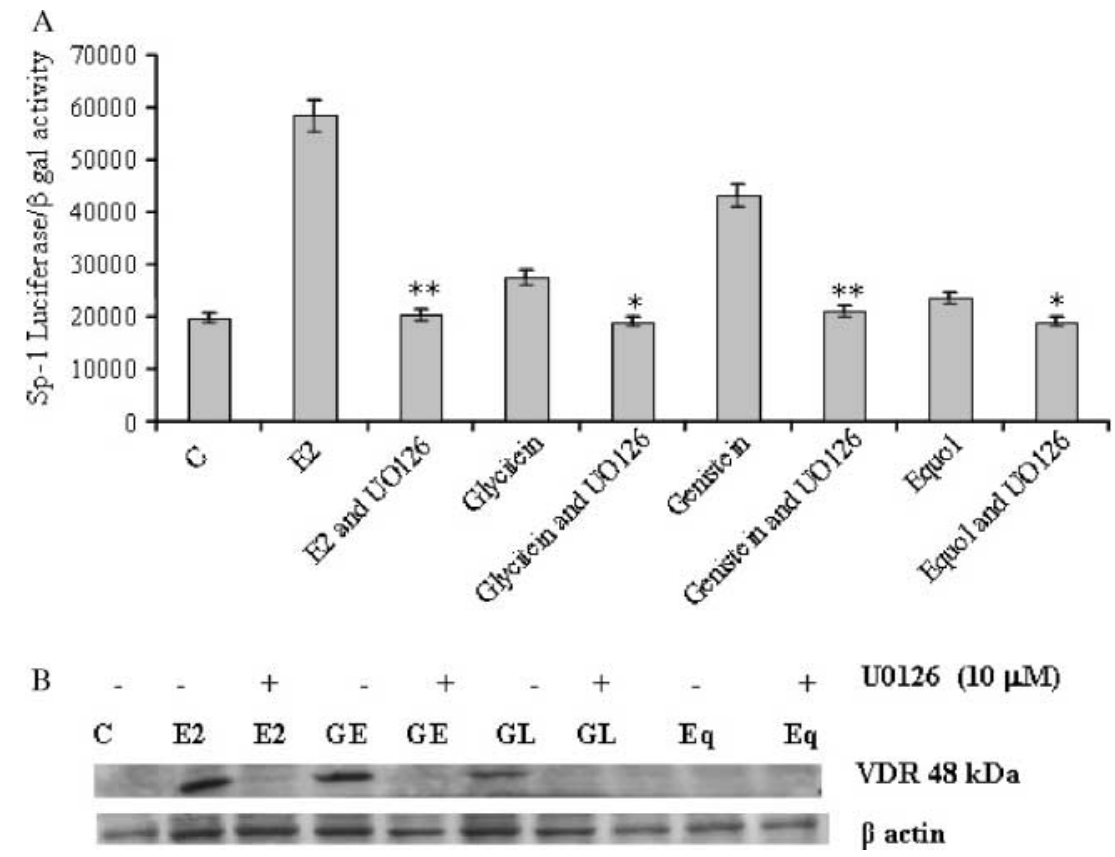

Figure 10 Effect of UO126 on Sp-1 activation and VDR expression. (A) HT29 cells were transfected with plasmids containing the $3 \times$ Sp- 1 fragment in a pGL2 basic vector in front of the luciferase reporter gene and then treated with $10^{-5} \mathrm{M}$ phytoestrogens, $10^{-8} \mathrm{M} \mathrm{E} 2$ in the presence or absence of $10^{-5} \mathrm{M} \cup 0126$. Cells were analyzed for luciferase activity $\left({ }^{*} P<0 \cdot 05, * * P<0 \cdot 01\right.$ compared with UO126 treatment to $\mathrm{E} 2$ and phytoestrogen treatment in the absence of UO126). (B) HT29 cells were treated with $10^{-5} \mathrm{M}$ phytoestrogens, $10^{-8} \mathrm{M}$ E2 in the presence or absence of $10^{-5} \mathrm{M} \cup 0126$ for 6 days. Cell extracts were analyzed by western-blot using a VDR antibody. One representative experiment of two identical ones is shown. The blots were stripped and re-probed with $\beta$-actin, which was used as a loading control. 


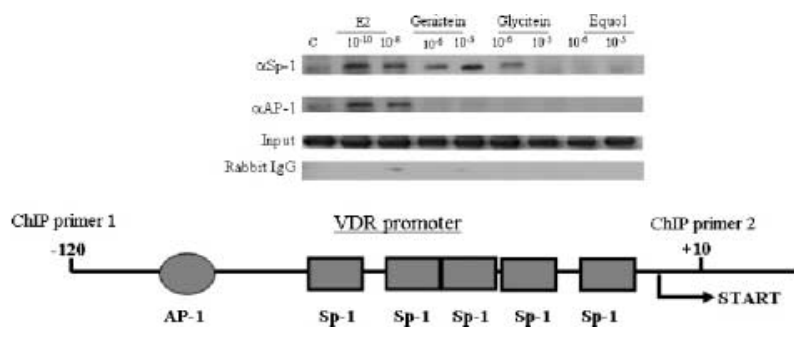

Figure 11 Effect of estrogen or phytoestrogen treatment on activation of AP-1 and Sp-1 transcription factors. (A) HT29 cells treated with different concentrations of E2, genistein, glycitein, or equol for $48 \mathrm{~h}$. In the ChIP assay to determine AP-1 transcription factor activation, treated cells were immunoprecipitated with cpan-Jun antibody. The immunoprecipitated DNA was purified and the region of the VDR promoter containing the AP-1 site (see diagram B) was amplified by PCR. In the ChIP assay to determine $\mathrm{Sp}-1$ transcription factor activation, cells treated as above were immunoprecipitated with $\mathrm{Sp}-1$ antibody. The immunoprecipitated DNA was purified and the region of VDR promoter containing various Sp-1 sites (see diagram B) was amplified by PCR. PCR analyses are representative of three independent ChIP assays. (B) Diagram illustrating the amplified portion of the VDR promoter in the ChIP assay.

expression in HT29 colon cancer cells, similar to the recently reported effects of E2 (Gilad et al. 2005). We found that genistein, glycitein and, albeit to a much lesser extent, equol, upregulate VDR transcriptional and translational activity. However, the effects induced by E2 were more pronounced than those obtained following phytoestrogen treatment at similar or even higher concentrations. In general, the most significant effects were exerted by genistein, and the weakest by equol, glycitein's effect being intermediate in this respect. The specific ER inhibitor ICI182, 780 blocked genistein- and glycitein-mediated VDR upregulation, similar to its inhibitory effect on E2 upregulation of VDR expression, suggesting that the phytoestrogens mediate VDR expression via a process involving ER. Since HT29 cells express only ER $\beta$ (Gilad et al. 2005), we conclude that phytoestrogens, similar to E2, upregulate VDR following binding to ER $\beta$.

Glycitein (4',7-dihydroxy-6-methoxyisoflavone) accounts for $5-10 \%$ of the total isoflavones in soy food products. A study of the competitive binding abilities of glycitein and E2 to ER has indicated that glycitein has weaker estrogenic activity than genistein (Song et al. 1999). This data could explain the weaker effect exerted by glycitein on VDR expression relative to $\mathrm{E} 2$ and genistein.

Equol was the least effective phytoestrogenic factor in the upregulation of VDR in HT29 cells. The explanation for this may reside in the fact that we utilized a racemic equol preparation and not pure enantiomers. Recently, Muthyala et al. (2004) reported that in binding assays, S-equol has a higher binding affinity with a preference for ER $\beta$ over ER $\alpha$ (ER $\beta / E R \alpha=13$-fold), which is comparable with that of genistein (ER $\beta / E R \alpha=16)$, than R-equol, which binds more weakly and with a preference for $\operatorname{ER} \alpha$ over $\operatorname{ER} \beta$ (ER $\beta$ / $\mathrm{ER} \alpha=0 \cdot 29)$. Therefore, a racemic preparation will bind less avidly to ER $\beta$, the main ER detected in HT29 cells (Gilad et al. 2005), and the active concentration able to bind to ER $\beta$ will be at most half, not accounting for the putative competition between the two enantiomers for binding to $\operatorname{ER} \beta$, or the steric disturbances involved in that competition.

Cotransfection of ER $\beta$ and VDR promoter significantly increased genistein and glycitein's ability to upregulate VDR expression, suggesting that $E R \beta$ is involved in the control of VDR activity. The effect of equol was less impressive and again, this may be due to the use of a racemic preparation. These results confirm the importance of ER $\beta$ expression in the VDR regulation exerted by either E2 or phytoestrogens.

Next, we aimed at analyzing downstream non-genomic signaling pathways, such as stimulation of kinase cascades induced by phytoestrogens and E2 in the regulation of VDR. Many different types of signaling machinery culminate in ERK activation, and different phytoestrogens may have differing abilities to activate distinct membrane-initiated signal cascades that lead to a variety of cellular functions (Watson et al. 2005). We tested the ability of genistein, glycitein, and the phytoestrogen metabolite equol to mimic E2's influence through activation of the ERK1/2 signaltransduction pathway (Gilad et al. 2005). We found that genistein and glycitein, similar to E2, exhibit temporal upregulation of ERK1/2 phosphorylation, while equol is less reactive in this regard. Genistein is an ER $\beta$-selective agonist of transcription (Mueller et al. 2004) and has a greater affinity for $E R \beta$ than $E R \alpha$. It seems that glycitein exerts similar effects. Equol was not effective in activating the ERK1/2 signal-transduction pathway. Again, the reason may be the use of a racemic preparation.

Since MAPK pathways (ERK, JNK, and p38) can activate AP-1 and Sp-1 sites and the E2 receptors $\mathrm{ER} \alpha$ and $\mathrm{ER} \beta$ modulate transcription of AP-1- and Sp-1-containing promoters, (Schultz et al. 2005), and since the VDR promoter contains Sp-1 and AP-1 consensus sites, we analyzed the role of these transcription factors in phytoestrogen regulation of VDR. We demonstrated a clear functional role for $\mathrm{Sp}-1$ binding sites in phytoestrogen regulation of the human VDR promoter. AP-1 binding sites within the VDR promoter are involved in mediating the effects of additional agents, such as forskolin, dexamethasone and certain growth factors (Byrne et al. 2000).

Our previous studies demonstrated that in HT29 cells, E2 upregulates VDR expression following binding to ER $\beta$, activation of signal-transduction pathways and expression of VDR by a mechanism involving the AP-1 site (Gilad et al. 2005). In the present study, we measured AP-1- and Sp-1driven luciferase activity and compared the ability of phytoestrogens to upregulate AP-1 and Sp-1 activity relative to that of E2. We observed a direct effect of Sp-1 transactivation and showed that activation of Sp-1 by E2 is similar to that exerted by genistein and glycitein, and to a lesser extent, equol. However, the phytoestrogens genistein, glyciten, and equol did not have E2's ability to upregulate VDR through the AP-1 transcription sites. 
These observations suggest that additional transcription binding sites present in this promoter, like AP-1, are required for regulation by E2 but not by phytoestrogens. Differential activation of AP-1 and Sp-1 by E2 and the phytoestrogens genistein, glycitein, and equol was further validated by ChIP assays. An increase in $\mathrm{Sp}-1$ binding to the respective consensus sites in the VDR promoter was obtained following treatment with E2 or the phytoestrogens genistein, glycitein and, to a lesser extent, equol. These results were in full agreement with the luciferase assays, in which we demonstrated similar activation of Sp-1 by E2 and the phytoestrogens. In contrast, gain in Jun binding was observed only in chromatin fractions immunoprecipitated with anti-pan-Jun antibody (which detects c-Jun, Jun B, and Jun C) from HT29 cells treated with E2 but not with the phytoestrogens, again supporting the results from the luciferase assays. The molecular basis and significance of the difference between E2 and phytoestrogens remain to be determined. We assume that the more pronounced effect exerted by E2 as compared with the phytoestrogens may reside in this difference in molecular targeting.

Our results indicate that genistein and glycitein, but not equol, can activate signal transduction similar to E2 and upregulate VDR transcription by regulating the $\mathrm{Sp}-1$ transcription factor. Similar to our studies, Wietzke and collaborators (Wietzke \& Welsh 2003, Wietzke et al. 2005), using reporter gene assays with truncated and mutated versions of GC-rich regions, identified three $\mathrm{Sp}-1$ consensus binding sites involved in the regulation of VDR promoter. Of particular interest, mutations in discrete $\mathrm{Sp}-1$ binding sites abolished the responsiveness of this promoter to $1,25(\mathrm{OH})_{2} \mathrm{D}_{3}$, estrogen and the phytoestrogen, resveratrol.

Luciferase reporter gene assays with the Sp-1-Luc vector revealed that $\mathrm{Sp}-1$ is inhibited by the specific MAPK kinase inhibitor UO126, just as occurs with VDR. These experiments allow us to conclude that upstream and downstream events in the signaling cascade are all interrelated and all participate in the control of VDR expression by E2 as well as by phytoestrogens

Vitamin D synthesizing (CYP27B1) and catabolic (CYP24) hydroxylases are synthesized also by colonocytes. To maintain colonic accumulation of $1,25(\mathrm{OH})_{2} \mathrm{D}_{3}$, its catabolism needs to be restricted. Cross et al. (2005) suggest that phytoestrogens in soy are responsible for decreased CYP24 expression. These assumptions were supported by the fact that $17 \beta$-estradiol can elevate CYP27B1 expression in rectal tissue of postmenopausal women. Our reported effect can be considered in addition to the effect reported by Cross et al. (2005) and emphasize the importance of phytoestrogens in relation to $1,25(\mathrm{OH})_{2} \mathrm{D}_{3}$ bioavailability.

Cumulatively, our results suggest that the enhanced consumption of soy products may correlate to a decreased incidence of colon tumorigenesis, which may be a direct consequence of enhanced expression of VDR and consequently enhanced bioavailability of $1,25(\mathrm{OH})_{2} \mathrm{D}_{3}$ impinging on vitamin D's anti-proliferative and pro-differentiation action.

\section{Acknowledgements}

The authors declare that there is no conflict of interest that would prejudice the impartiality of this scientific work.

\section{References}

Alexaki VI, Charalampopoulos I, Kampa M, Nifli AP, Hatzoglou A, Gravanis A \& Castanas E 2006 Activation of membrane estrogen receptors induce pro-survival kinases. Journal of Steroid Biochemistry and Molecular Biology 98 97-110.

An J, Tzagarakis-Foster C, Scharschmidt TC, Lomri N \& Leitman DC 2001 Estrogen receptor beta-selective transcriptional activity and recruitment of coregulators by phytoestrogens. Journal of Biological Chemistry 276 17808-17814.

Beck V, Rohr U \& Jungbauer A 2005 Phytoestrogens derived from red clover: an alternative to estrogen replacement therapy? Journal of Steroid Biochemistry and Molecular Biology 94 499-518.

Black AR, Black JD \& Azizkhan-Clifford J 2001 Sp1 and kruppel-like factor family of transcription factors in cell growth regulation and cancer. Journal of Cellular Physiology 188 143-160.

Branca F 1999 Physical activity, diet and skeletal health. Public Health Nutrition 2 391-396.

Branca F 2003 Dietary phyto-oestrogens and bone health. Proceedings of the Nutrition Society $62877-887$.

Branca F \& Lorenzetti S 2005 Health effects of phytoestrogens. Forum of Nutrition $\mathbf{5 7}$ 100-111.

Byrne IM, Flanagan L, Tenniswood MP \& Welsh J 2000 Identification of a hormone-responsive promoter immediately upstream of exon $1 \mathrm{c}$ in the human vitamin D receptor gene. Endocrinology 141 2829-2836.

Chang WC \& Chen BK 2005 Transcription factor Sp1 functions as an anchor protein in gene transcription of human 12(S)-lipoxygenase. Biochemical and Biophysical Research Communication 338 117-121.

Chatterjee B, Echchgadda I \& Song CS 2005 Vitamin D receptor regulation of the steroid/bile acid sulfotransferase SULT2A1. Methods in Enzymology 400 165-191.

Cos P, De Bruyne T, Apers S, Vanden Berghe D, Pieters L \& Vlietinck AJ 2003 Phytoestrogens: recent developments. Planta Medica 69 589-599.

Cross HS, Kallay E, Lechner D, Gerdenitsch W, Adlercreutz H \& Armbrecht HJ 2004 Phytoestrogens and vitamin D metabolism: a new concept for the prevention and therapy of colorectal, prostate, and mammary carcinomas. Journal of Nutrition 134 1207S-1212S.

Cross HS, Bises G, Lechner D, Manhardt T \& Kallay E 2005 The vitamin D endocrine system of the gut - its possible role in colorectal cancer prevention. Journal of Steroid Biochemistry and Molecular Biology 97 121-128.

Dixon RA 2004 Phytoestrogens. Annual Review of Plant Biology 55 225-261.

Dopp E, Vollmer G, Hahnel C, Grevesmuhl Y \& Schiffmann D 1999 Modulation of the intracellular calcium level in mammalian cells caused by 17beta-estradiol, different phytoestrogens and the anti-estrogen ICI 182, 780. Journal of Steroid Biochemistry and Molecular Biology 68 57-64.

Dynan WS \& Tjian R 1983 Isolation of transcription factors that discriminate between different promoters recognized by RNA polymerase II. Cell 32 669-680.

Escaleira MT, Sonohara S \& Brentani MM 1993 Sex steroids induced up-regulation of 1,25-(OH)2 vitamin D3 receptors in T 47D breast cancer cells. Journal of Steroid Biochemistry and Molecular Biology 45 257-263.

Gilad LA, Bresler T, Gnainsky J, Smirnoff P \& Schwartz B 2005 Regulation of vitamin D receptor expression via estrogen-induced activation of the ERK $1 / 2$ signaling pathway in colon and breast cancer cells. Journal of Endocrinology 185 577-592.

Jochum W, Passegue E \& Wagner EF 2001 AP-1 in mouse development and tumorigenesis. Oncogene 20 2401-2412.

Levy J, Zuili I, Yankowitz N \& Shany S 1984 Induction of cytosolic receptors for 1 alpha, 25-dihydroxyvitamin D3 in the immature rat uterus by oestradiol. Journal of Endocrinology 100 265-269. 
Liel Y, Kraus S, Levy J \& Shany S 1992 Evidence that estrogens modulate activity and increase the number of 1,25-dihydroxyvitamin D receptors in osteoblast-like cells (ROS 17/2.8). Endocrinology 130 2597-2601.

Liel Y, Shany S, Smirnoff P \& Schwartz B 1999 Estrogen increases 1,25dihydroxyvitamin $\mathrm{D}$ receptors expression and bioresponse in the rat duodenal mucosa. Endocrinology 140 280-285.

Maggiolini M, Vivacqua A, Fasanella G, Recchia AG, Sisci D, Pezzi V, Montanaro D, Musti AM, Picard D \& Ando S 2004 The G protein-coupled receptor GPR 30 mediates c-fos up-regulation by 17 beta-estradiol and phytoestrogens in breast cancer cells. Journal of Biological Chemistry 279 27008-27016.

Morley P, Whitfield JF, Vanderhyden BC, Tsang BK \& Schwartz JL 1992 A new, nongenomic estrogen action: the rapid release of intracellular calcium. Endocrinology 131 1305-1312.

Mueller SO, Simon S, Chae K, Metzler M \& Korach KS 2004 Phytoestrogens and their human metabolites show distinct agonistic and antagonistic properties on estrogen receptor alpha (ERalpha) and ERbeta in human cells. Toxicological Sciences 80 14-25.

Muthyala RS, Ju YH, Sheng S, Williams LD, Doerge DR, Katzenellenbogen BS, Helferich WG \& Katzenellenbogen JA 2004 Equol, a natural estrogenic metabolite from soy isoflavones: convenient preparation and resolution of $\mathrm{R}$ - and S-equols and their differing binding and biological activity through estrogen receptors alpha and beta. Bioorganic and Medicinal Chemistry 12 1559-1567.

Nethrapalli IS, Tinnikov AA, Krishnan V, Lei CD \& Toran-Allerand CD 2005 Estrogen activates mitogen-activated protein kinase in native, nontransfected CHO-K1, COS-7, and RAT2 fibroblast cell lines. Endocrinology 146 56-63.

Schultz JR, Petz LN \& Nardulli AM 2005 Cell- and ligand-specific regulation of promoters containing activator protein-1 and $\mathrm{Sp} 1$ sites by estrogen receptors alpha and beta. Journal of Biological Chemistry 280 347-354.
Schwartz B, Smirnoff P, Shany S \& Liel Y 2000 Estrogen controls expression and bioresponse of 1,25-dihydroxyvitamin $\mathrm{D}$ receptors in the rat colon. Molecular and Cellular Biochemistry 203 87-93.

Song TT, Hendrich S \& Murphy PA 1999 Estrogenic activity of glycitein, a soy isoflavone. Journal of Agricultural and Food Chemistry 47 1607-1610.

Studzinski GP, Wang X, Ji Y, Wang Q, Zhang Y, Kutner A \& Harrison JS 2005 The rationale for deltanoids in therapy for myeloid leukemia: role of KSR-MAPKC/EBP pathway. Journal of Steroid Biochemistry and Molecular Biology 97 47-55.

Suske G 1999 The Sp-family of transcription factors. Gene 238 291-300.

Valachovicova T, Slivova V \& Sliva D 2004 Cellular and physiological effects of soy flavonoids. Mini Reviews in Medicinal Chemistry 4 881-887.

Watson CS, Bulayeva NN, Wozniak AL \& Finnerty CC 2005 Signaling from the membrane via membrane estrogen receptor-alpha: estrogens, xenoestrogens, and phytoestrogens. Steroids 70 364-371.

Wietzke JA \& Welsh J 2003 Phytoestrogen regulation of a vitamin D3 receptor promoter and 1,25-dihydroxyvitamin D3 actions in human breast cancer cells. Journal of Steroid Biochemistry and Molecular Biology 84 149-157.

Wietzke JA, Ward EC, Schneider J \& Welsh J 2005 Regulation of the human vitamin D3 receptor promoter in breast cancer cells is mediated through Sp1 sites. Molecular and Cellular Endocrinology 230 59-68.

Yan C, Naltner A, Conkright J \& Ghaffari M 2001 Protein-protein interaction of retinoic acid receptor alpha and thyroid transcription factor-1 in respiratory epithelial cells. Journal of Biological Chemistry 276 21686-21691.

Zivadinovic D \& Watson CS 2005 Membrane estrogen receptor-alpha levels predict estrogen-induced ERK1/2 activation in MCF-7 cells. Breast Cancer Research 7 R130-R144.

Received in final form 24 July 2006

Accepted 26 July 2006 